\title{
Phenomenology Study on the Financial Motive and Shift of Norm Through the Perspective of Psychological Egoism and Activation of Scott on Cafe Business Environment in the City of Blitar, East Java, Indonesia
}

\author{
Fitriana Santi ${ }^{1}$, Dr. Nurika Restuningdiah ${ }^{2}$, Dr. Satia Nur Maharani ${ }^{2}$ \\ ${ }^{1,2,3}$ Universitas Negeri Malang
}

\begin{abstract}
Phenomenology Study on the Financial Motive and Shift of Norm through the Perspective of Psychological Egoism and Activation of Scott on Cafe Business Environment in the city of Blitar, East Java, Indonesia.The flow of globalization that has become more rapid resulted in rapid changes in the pattern of community life into modernization. The change in lifestyle has apparently been used by businesses to provide places such as cafes. The existence of cafe does not necessarily have a positive impact in economic terms, but in fact have a negative effect when viewed from the social side of the hedonic behaviors that leads to consumptive behavioral. The spread of cafe in the city of Blitar raises a big question whether the social norms from business activities are sacrificed just because of financial motives. This study aimed to determine how financial motives capable of shifting social norms that exist in the city of Blitar. This research was included in qualitative research. The underlying reason to self-employed is financial motives. Their financial motives tempting to make them more incentive to establish a business strategy in order to attract consumers. Not only financial motives of the business owner, but found a motive for having fun on the side of consumers that make cafe business increasingly flourishing. The results also showed that the presence of motive for economic improvement from the relevant agencies. This suggests that lifestyle changes toward modernization that has been exploited by the owners of cafes and related agencies in order to reap the benefits without realizing the impact of those decisions. One impact reflected in the student of Blitar City is a hedonistic lifestyle that leads to consumerism.
\end{abstract}

Keyword: Financial Motives, Shift of Norm

\section{Introduction}

Globalization which has become more rapid results in rapid changes in the pattern of community life. The change can be seen from the development of technology, lifestyle, and increasingly modern customs. Whether we realize it or not, this modernization will establish new patterns of behavior which is typical, leading to the formation of a new lifestyle. This modernization has also penetrated into traditional society, as happened in the city of Blitar. Changes in people's lifestyles in the City of Blitar, especially the students, it can be seen from how they allocate money and time for activities such as "ngafe" (an activity of going to a café). Based on the observations of the researcher over 8 years ago, students in Blitar go out of the house just to do productive activities, such as work group, go to tutoring, or chores at internet cafes (cafe). But what happen today is very contradictory, where students are fonder of going to cafe for "hanging out" or simply take advantage of the "WiFi" for nonproductive purposes. This is one picture of a lifestyle that shows a shift in the norm, in which the productive activity has been shifted by non-productive activities.

Not only that, it seems the lifestyle changes have been used by businesses to provide places such as cafes, shopping malls and karaoke. The high demand for market making businesses interested in doing business in the field. The positive impact of the business establishment can be felt in terms of the economy, such as reduced unemployment. It is therefore not surprising that in the city of Blitar businesses are increasingly spreading such as cafes, and even many businesses that divert their original business to cafe business on the grounds that the cafe business is more profitable than any other business or enterprise. The whole cafe in the city of Blitar is open from 10.00 until at 02..00. Based on observations made by the researcher, some cafes began bustling at 12.00 , ie at a time when some students are going home from school and many of them are hanging out from the afternoon until late at night.

At first, the habit of gathering in cafes is merely for leisure and rest. However, over the times, cafes have contributed to the formation of a lifestyle, especially for students. Dimyati (2009) in his study results that "cafe has become a place of exile for individuals who like to make a place to gather and interact with other people who later form the behavior patterns of their lifestyle". The development of cafe raises major questions, whether social norms of business activities are sacrificed just because of financial motives? Are employers only pursue financial gain? Often financial motives encourage the violation of norms and made a selfish decision. Scoot activation theory (1992) suggests that the activation of the stimulation level in reticular system of the 
brain that encourages any action. Similar to financial motives that can stimulate the brain and commanding someone to do it for the resources of its activities.

The financial motive is also a form of entry into force of the theory of psychological egoism Rachel (2004), in which self-interest motivates any action. The phenomenon also occurred in the city of Blitar, which is committed to become a city that is far from the icon of capitalism or the nature of hedonism. But as the development of the times and the increasing demands of life, Blitar city has followed the modernization. Businesspersons become easier to obtain permission to build a modern entertainment places, such as cafes. Some of the descriptions above tickles the researcher to determine whether "money talk" when businesses run into a dilemma in choosing between social norms and financial benefits. The existence of cafes does not necessarily have a positive impact in economic terms, but in fact they have a negative effect when viewed from the social side. Young consumers which consist of students and even student, became an easy target for the capitalists to support their interests. One effect of this capitalism is the rampant of consumptive behavior.

\section{Reason to be Entrepreneur:}

\section{Discussion}

There are various reasons why a person chooses to be an entrepreneur, as expressed by the cafe owner Matoa, where he chose to be an entrepreneur and left his title as one of the youngest and the best manager in East Java in one of the private banks. The reason for this is that he wanted to have many quality time for family, his desire to become a leader as well as free in the sense that there are no rules or stress at work. In addition to the lure of a larger source of income which was also coloring the reasons behind the establishment of the cafe. This is evident from their focus in generating profit. Some of these reasons made them choose entrepreneurship and sacrifice their comfort zone. This is in line to theopportunity costtheory.

Some employers even, are faced with the choice to be selected at a time i.e. to keep on being a worker at a quite high salary or choose entrepreneurship. From the choice they prefer to become entrepreneurs with various consequences. Opportunity costs sacrificed by some owners of this cafe is the loss of salary that is quite large. Based on the concept ofopportunity cost mentioned above, it is known that they prefer to be an entrepreneur, because it gives benefit in a form of materials more compared to be an employee.

\section{Financial Motive behind the Establishment of Café:}

As explained earlier, one factor driving a person choosing to be an entrepreneur is that he/she desires to gain more profits than being a worker. This is the reason that has made some employers like to collect the maximum profit. It is not wrong if it does not impact on the surrounding community, but it will be a problem if one of the ways used by some employers had a negative impact on students. There are various strategies used by the cafe owner to restrain the consumer, namely by giving more services in a productive day (Monday-Friday). Such services includelive music, discounts and provision ofmember. Act of giving's strategy is in line with the activity theory by Scott (1992) that suggests that the activation theory is the level of stimulation to the brain reticular system.

The area ofbrainreticular which correlates to the action command for the activation source isPrefontal Cortex (PFC) with Amygdala. PFC itselfis part of brain lobus frontal (the front of the large cerebral hemispheres) is located in the front area of motor skills and pre-motor. These brain regions involved in cognitive behavioral ability of expressing personality, decision-making and moderator of social behavior.Amygdala is the part that has the complexity of the structure, engaged in a large number of particularly affective abilities to process signals of emotion.

The cafe owner phenomenon suggests that an error occurred in the PFC section of the brain, that they can not distinguish between good and bad. Giving excessive strategy and have a negative impact shows that many of them are not able to assess the adverse effects that occurred against the decision. The lack of funciton of amygdala is also evident from the absence of fear for cafe owners about the negative impact. Those with a taste without a guilt continues to make a profit even if it costs social norms. Their financial motives is what ultimately made the irrational behavior.

In fact, the actions of these strategies have a positive impact for the owner of the cafe. Most of the customers are interested to take advantage of discounts offered and also the manufacture of mamber, so it is no question that during productive days and hours cafe str visited by consumers until morning. The above facts indicate that the motive does not only appear on the side of the cafe owner, but also from consumers, especially students. The motive or the urge to have fun is what makes them (consumers) like to do routines in the cafe. The second meeting of the motives are what make reticular of brain in PFC and amygdala to act irrationally. An irrational act that is reflected on the phenomenon that occurs is the implementation of a business strategy by the owner of the cafe at the expense of the norms of students of Blitar city.

In fact the response from consumers resulted them to hang out until late at night. The meeting between the finance motive by the cafe owners and the motive of a pleasure by the students produce behavior far from 
Phenomenology Study on the Financial Motive and Shift of Norm Through the Perspective of...

business ethics. When viewed from the economic point of the act of giving strategy done by the cafe owner is fine to be performed, but when viewed from the social side it is able to provide a negative impact on student behavior. One reflection of negative behavior is the hang out activity until late at night. Based on observations of the researcher the activities they do in the cafe until late at night is not a productive activity, such as watching soccer game, just chat with friends or even gambling. The researcher tried to dig again whether it does not violate the rules. The answer from the cafe owner turned out to be astounding, that implied the sentence "as long as it benefits me why not?

The above facts suggest that the motive of finance which made some businesses more viable developing strategy to attract consumers. Some of the above is a manifestation of the entry into force of psychological egoism theory which states that every human action is motivated by self-interest. The applicability of this theory is reflected in the sentence pronounced by the cafe owner "as long as it benefits why not?". Some strategies given by the owner of the cafe, not merely for the satisfaction of the consumer, but the owner of the cafe itself. It is no question that they are becoming increasingly bold and enterprising founded the cafe, because of the ease in obtaining a license. The result of the researcher interviews with one of the employees of the department of tourism it is known that the establishment of the current cafe is not as complicated as a few years ago.

Ease of granting a license has a positive effect of reducing unemployment. But the ease of licensing is not balanced with the established regulations which will cause an imbalance that resulted in the shifting of norms. Once more, the phenomenon shows that the motive of meeting is not only financial motives (owner of cafe) and pleasure (students), but also discovered a new motive from the relevant department. The motive is economic improvement that makes this department simply grants permission without preconditions of regulations for the owner of the cafe. Again, the theory of psychological egoism applies in this case. Viewing from the absence of rules provided by the related department regarding closing hours of cafes proves that, what they do is purely for their own interests. Without them knowing the students today have been sacrificed by them for the sake of private interests. Similar to the results of the above studies, that the lure of financial incentives are what make them easy to give a license for establishing cafes.

\section{Students' Lifestyle in Blitar City:}

Theory of modernization (1950) stated that modernization is based on the dichotomy between what is called modern and what is called traditional, modern is a symbol of progress and traditional is a symbol of society that has not been developed. Modernization is the process by which individuals change from the traditional way of life toward more complex lifestyle and technologically advanced and rapidly changing. Modernization has also been expanded to Blitar city society especially students. Changes in the direction of modernization can be seen from lifestyle changes that occur among students in Blitar city.

Lifestyle is closely related to how someone forms an image in the eyes of others, it is due to social status owned. According to Supranto and Limakrisna (2011: 142), lifestyle affects all aspects of a person's consumption behavior (consumer). Today's consumer society has grown in tandem with the history of economic globalization and the transformation of consumer capitalism. This condition is characterized by the proliferation of shopping centers, entertainment centers such as karaoke bars or cafes. The habits ofhangoutafter school, and often gather together at night in entertainment places such as café and karaoke, led to a new term "to hang out in café look cool", which leads to the spread of establishment of café in Blitar City.

Based on the explanation above it can be concluded that lifestyle changes of students in Blitar City is geared from 3 motives namely financial motives, desires and economic improvement. Financial motives that emerged from the cafe owner is making them increasingly keen to attract consumers in various ways. The desire of consumers to always have fun also has made them from day to day utilize the discounting of the cafe. Not forgetting that the department also participated in their motive of economic improvement which has become the root of this problem. This fact shows that among the three motives, they are what makes changes toward modernization.

\section{Hedonism Lifestyle:}

Changes in lifestyle of students in Blitar city caused by the presence of motive of a pleasure has formed a new lifestyle namely hedonism. Hedonistic lifestyle can be defined as a pattern of living that emphasizes its activities to seek pleasures of life, such as more frequent use of the time outside their home to satisfy their needs. Observations and interviews also indicate that the routine of the students are often done outside home. The average student activities started from 07:00 to 14:00, for productive activities or school hours. After that they go home and just changed clothes, then go for tutoring until late at night.

But unfortunately some students met by the researcher, was using tutoring as an excuse to be able to go to a cafe. Many of those who skipped tutoring class were just hanging out at cafes. Most of them said that the 
reason to go to the cafe is to eliminate boredom at home. They recognize that when they are at home, they will be required to study, it is this which makes them to be more fond being outdoors.

The majority of students are competing and dreaming to be able to live a luxurious life. Spree and hang out in cafes, and karaoke is part of the agenda of their lives. Most of them just wanted to join in activities that are considered well-known, namely hanging out in cafe. Hedonistic lifestyle is very interesting for the students, so it has tremendous allure. The phenomenon happening shows that the tendency of students to choose to live a more comfortable or instant, luxurious and all-sufficient.

The presence of cafes utilized by consumers but especially the students to isolate themselves and form new subcultures. The formation of this new subculture is evident from their community formed in some cafes, ranging from ball community up to photography community. They use cafe as a meeting place or commonly referred to basecame, assuming that a particular activities will be more meaningful if it is done in cafe.

Again, the phenomenon shows that financial motives owned by the owner of cafe has an impact on students. These impacts are realized from the accomplishment of motive such as pleasures they had. The owner of the cafe who day after day provides a convenient place has made them to behave hedonist, making them even more fond of hang out rather than stay at home. Without the notice of the official a change in lifestyle has penetrated to the students in the city of Blitar. This is the impact from them on the motive of economic improvement. The meeting of the three motives have caused changes in lifestyle towards modernization realized from the lifestyle of hedonism.

\section{Consumptive Lifestyle:}

Changes in lifestyle seems not only to hedonism alone but began to lead to the consumptive lifestyle. Currently the lifestyle of students in the city of Blitar resembles the lifestyle of students in large cities, both in terms of appearance, or a place to hang out. It can be seen from the proliferation of business centers such as cafe or karaoke bars, which became a favorite place for students in Blitar city.

Adolescents are used as an easy target by businesses because adolescents have high curiosity to try new things. In addition, the crisis of confidence has made a teenager in a state of instability, which ultimately drives the desire to conform in order to be accepted by the group. Students in Blitar also assume that they will look cool and hip when hanging out in cafes.

Evidence from the field suggests that most students use their pocket money to go to cafe. This shows that the theory of modernization that led to the symbol of progress also colored reasons as to why they go to cafe. Modernization of lifestyle changes is what led them to new habits namely hang out in cafe, resulting in consumptive behavior.

Based on this phenomenon it is now known the presence of unbalanced behavior that occurs in students. According to the theory of Kurt Lewin (1970) human behavior is a state of balance between the driving force and anchoring. However, this behavior may change when there is an imbalance between the two forces. The realization of the enactment of this theory into consumptive behavior is an imbalance between the driving force to follow the trend greater than anchoring strength.

Consumptive behavior is what makes the cafe owner to be increasingly aggressively implementing a strategy to achieve higher profits. Cafe owners behavior indicates that the motive they have are not the motive of consumers satisfaction, but financial motives.

Their focus on the implementation of the strategy are for its own interests namely make higher profits. Do not blame the owner of the cafe, because the fact is that there are no rules or bans from the relevant office regarding closing hours of cafe or restriction for children in uniform hanging out in cafes. Just because the motive is economic improvement that impacts on consumptive behavior change. This phenomenon is used by students to satisfy their consumptive desires. This suggests the presence of pleasure motive owned by students. The meeting of the three motives are what causes modernization reflected from consumptive behavior.

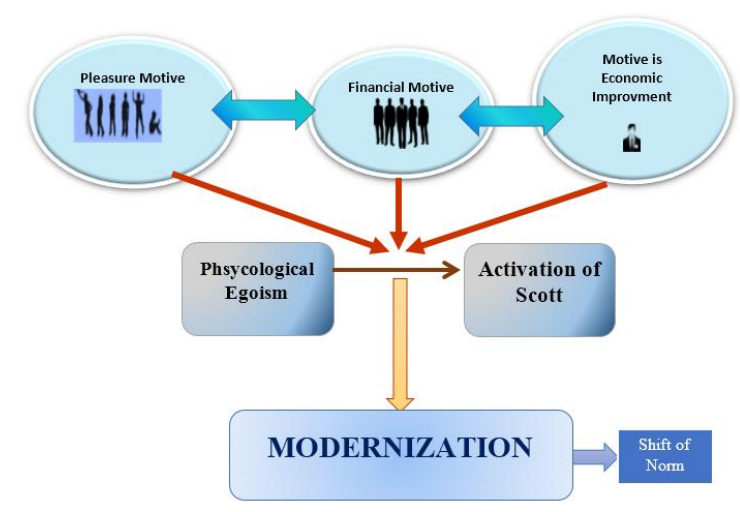




\section{Formulation of Concept}

Motive is an impulse that drives a person to behave because of the presence of needs to be met by somebody. , Based on the research results, found three motives from various parties. The first is financial motive owned by the owner of a cafe, the second is economic improvement and the third motive is the motive of pleasure owned by students (consumers).

Financial motives reflected in the cafe owner is evident from the decision-making action. The fact shows that there are many of those who switched professions from employees to become entrepreneurs. The underlying reason is the desire to make more profit.

Various strategies given starting from giving discounts, member to the provision of entertainment facilities to gain higher profits. In fact the provision of this strategy are to attract consumers every day, and most consumers are students.

Some students are also often found absent in school hours just to go to a cafe. This indicates that a cafe has become a place of exile for students. Often they use the time at the cafe to show that hedonistic lifestyle began attacking students in the city of Blitar. Style changes are not stopping at hedonism, but it began to spread in the consumptive lifestyle. Some of the changes mentioned above indicate a motive of pleasure from the students.

Motive of pleasure arising in students is utilized by the cafe owner to make a profit. Not just stopping at the pleasure motive. After digging again it turned out to be the root of this phenomenon is the presence of economic improvement which is owned by the related department. This motive is evident from the absence of regulation given to the owner of a cafe. Whereas a regulation is essential in order to maintain a principle. The principle of Blitar city that was originally committed to be far away from the capitalist icons and hedonistic lifestyle began to fade because of the presence of economic improvement motive.

The synergy of the three motives that reflect the realization of the theory of psychological egoism . This theory states that every human action is basically motivated in their own interest. It is impossible that the implementation of the strategy by the cafe owner is solely for customer satisfaction. It must have been that behind it implies self-interest to make more profit. Similar to the department that provides ease of establishment of cafes which is solely to reduce unemployment. It is impossible that they are only thingking of others, there must be bigger above the interests of others and it is self-interest. Similarly with the students themselves who are only concerned with the satisfaction of themselves. The presence of enforceability of theory of psychological egoism is what brought the Blitar city lifestyle changes toward modernization.

Based on the above problems according to the researcher there needs for a new breakthrough in the form of a new movement of "financial mental revolution". Financial mental revolution is a massive movement or radical changes related to mental in this case related to finance. Revolution is necessary so that businesses are able to form a character or a private firm on business ethics. The presence of mental finance revolution is expected to that businesses to keep running the prevailing moral standards, meaning that they do not only focus on the acquisition of profit, but also pay attention to the impact to the surrounding community. Mental revolution could be initiated by the self-consciousness of the importance of social responsibility.

\section{Conclusion}

Based on the above explanation, it can be concluded that, today the city of Blitar society has undergone modernization lifestyle changes. Changes in lifestyle is then used by the owners of capital to set up some business units, one of them is in a form of cafes. Some employers revealed that café business is able to guarantee a profit, it is evident from many of them are converted into self-employment.

Many of the strategies used by businesses in order to gain more profits. Without them knowing the implementation of the strategy and they took full advantage of their focus had a negative impact for consumers especially students. Frequent gathering or hang out in a cafe has made them to behave as an hedonist that gives arise to hedonistic lifestyle. Hedonic behavior seen from their habitual use of time outside home. Often, too, they are found skipping "tutoring class" only to hang out in cafes.

Many of those who feel that the activities would be more helpful when it is done in a cafe. This shows that there is a motive of pleasure from the students. Not just stopping at the hedonistic lifestyle, but this lifestyle has penetrated into consumptive lifestyle. Consumptive lifestyles can be seen from the way they allocate money only for the tertiary course. Some of the impacts mentioned are those that never been crossing in the minds of the owners of capital, thus without them knowing they are capable of shifting norms of behavior in the City of Blitar.

City of Blitar, which was originally a city far away from capitalist icon, today has been inversed simply because of financial motives. At first Blitar committed to keep its traditionality, in order to avoid the behavior of hedonism and consumerism. However, as time passes the desire fades just because of financial incentives.

Not only business people who have to account for it, but the department related is also contributing in this regard. Ease of acquisition of licenses has made businesses to be more incentive to run its activities. The 
lack of regulation leads them to act in such a way. The phenomenon shows that the party related also has a motive namely motive of economic improvement.

The three synergies that exist are those which then form a change in the City of Blitar which is a change in the direction of modernization. Changes if it is not balanced by rules will bring an imbalance, causing a shift in the norm. One way to handle this is to create a new movement that begins with the financial mental revolution. A massive movement to improve mental from the various parties. Self-awareness also contributes in this financial mental revolution movement.

\section{Reference}

[1] Adler Alfred. Boeree, C. Alfred Adler. 1997. Personality Theories.

[2] Bogdan, Robert C; Biklen, Knopp Sari. 1982. Qualitative Research for Education; An Introducyion to Theory and Methods. Boston London

[3] Creswell, J.W. 2010. Research Design: Pendekatan Kualitatif, Kuantitatif, dan Mixed, Edisi Ketiga. Yogyakarta: Pustaka Pelajar.

[4] Dimyati, N.S. 2009. Komunitas Kafe sebagai Gaya Hidup, (online), (http://digilib.uin-suka.ac.id), diakses 10 Januari 2015

[5] Fessler, N. J. 2003. Experimental Evidence on the Links among Monetary Incentives, Task Attractiveness, and Task Performance. Journal of Management Accounting Research, Vol. $15,161-176$.

[6] Fitri N. 2006. Motif Sosial

[7] Frinces, Z.H. 2010. Pentingnya Profesi Wirausaha di Indonesia. Jurnal ekonomi \& Pendidikan, 7.24-57

[8] Gardner Lindzey, calvin S. Hall dan Richard F. Thompson. 1975. Psychology.

[9] Hong, H \& Kacperczyk, M. 2009. The Price of Sin: The effects of Social Norms on Markets. Journal of Financial Economics. 93: $15-36$

[10] John Mowen dan Michael Minor 2002. Consumer Behavior Edisi 5: Hardcover

[11] Jong \& Wennekers. 2008. Conceptualizing Entre-preneurial Employee Behavior", SMEs and Entrepreneurship Programme Finance by the Netherlands Ministry of Economic Affairs, diakses 1 Januari 2015

[12] Kurt Lewin. 1970.Resolving social conflicts and field theory in social science, Washington, DC: American Psycho-logical Association.

[13] Liu, Yanju dkk. 2014. Iss Sin Always a Sin? The interaction Effect of Social Norms and Financial Incentives on Market Participants' Behaviour. Accounting, Organization and Society 39 (289-307), diakses 10 September 2014

[14] Pinder, C. C. 1997. Work Motivation in Organizational Behavior. New Jersey: Prentice Hall.

[15] Schutz, A. 1970. On Phenomenology and Social Relations. Chicago: The University of Chicago Press

[16] Scott, W. E., Jr. (1966). Activation theory and task design. Organization Behavior and HumanPerformance, 25, 311-325.

[17] Thompson, L \& Loewenstein G. 1992. Egocentric Interpretations of Fairness and Interpersonal Conflict. Organizational behaviour and human decision processes, 51. 176-19 